\title{
NER300: Success or Failure of Public Support for Low-emission Technologies?
}

\section{NER300: sukces czy porażka publicznego wsparcia technologii niskoemisyjnych?}

\section{Grażyna Borys}

\author{
Ul. Wotkowa 30, 58-500 Jelenia Góra, Poland \\ e-mail:g.borys@wez.uz.zgora.pl
}

\begin{abstract}
The Paris Agreement of December 2015 set a very ambitious target for the global reduction of greenhouse gases. Its implementation means the need to transform the global economy, including the European one, towards the economy characterised by the neutral level of these gases emission. Such transformation will not be possible without the dynamic development of breakthrough technological innovations on a large scale, which requires significant financial support from the public sector. This support should be primarily focused on the demonstration phase of the innovation process, which frequently turns into the so-called technological death valley. Demonstration projects are not commercial products as yet, they are characterized by untested technical reliability and the risk of no demand for products manufactured using new technologies. Therefore, private investors are not entirely willing to invest in them. In 2009 the European Union, in order to avoid the death valley, launched, through the promising innovative low-emission technologies, the NER300 programme - one of the world's largest programmes supporting the supply of low-carbon commercial technologies, as one of the components of the Emissions Trading System - ETS. This programme is the subject of the presented article. Its purpose is to provide answers to three basic questions: 1) did the programme end with a success or a failure?; 2) what external and internal reasons determined the results of the programme?; 3) should the programme become a systemic element of the EU ETS?

The article presents the results of NER300 and their interpretation in the context of the programme's objectives. The research covering the reasons which determined the results of the programme used the existing subject literature on the NER300 programme and the special report issued by the European Court of Auditors presenting these results as well as the selected European Union documents and normative acts.
\end{abstract}

Key words: climate protection, technological valley of death, programme NER300

\section{Streszczenie}

Porozumienie paryskie z grudnia 2015 r. wytyczyło bardzo ambitny cel światowej redukcji gazów cieplarnianych. Jego realizacja oznacza konieczność transformacji gospodarki globalnej, w tym europejskiej, w kierunku gospodarki o neutralnym poziomie emisji tych gazów. Taka transformacja nie będzie możliwa bez dynamicznego rozwoju przełomowych innowacji technologicznych na dużą skalę, co wymaga znaczącego finansowego wsparcia sektora publicznego. Wsparcie to powinno być ukierunkowane zwłaszcza na fazę demonstracyjną procesu innowacyjnego, która bardzo często zamienia się w tzw. technologiczna dolinę śmierci. Projekty demonstracyjne nie są jeszcze produktami komercyjnymi, cechuje je niesprawdzona niezawodność techniczna oraz ryzyko braku popytu na produkty wytwarzane przy pomocy nowych technologii. Dlatego inwestorzy prywatni nie chcą w pełni w nie inwestować. Unia Europejska, w celu uniknięcia doliny śmierci przez obiecujące, innowacyjne technologie niskoemisyjne uruchomiła w 2009 r. program NER300 - jeden z największych na świecie programów wspierających podaż komercyjnych technologii niskoemisyjnych, jako jeden z elementów systemu handlu emisjami (emissions trading system - ETS). Program ten jest przedmiotem tego artykułu. Jego celem jest udzielenie odpowiedzi na trzy zasadnicze pytania: 1) czy program zakończył się sukcesem czy porażką/; 2) jakie przyczyny zewnętrzne 
i wewnętrzne zadecydowały o wynikach programu?; 3) czy program powinien stać się systemowym elementem EU ETS?

W artykule prezentowane są wyniki NER300 i ich interpretacja w kontekście celów programu. W badaniach nad przyczynami, które zadecydowały o wynikach programu wykorzystana została dotychczasowa literatura o programie NER300, specjalny raport Europejskiego Trybunału Obrachunkowego prezentujący te wyniki oraz wybrane dokumenty i akty normatywne Unii Europejskiej.

Słowa kluczowe: ochrona klimatu, technologiczna dolina śmierci, program NER300

\section{Background}

The Paris Agreement of December 2015 set the global goal of reducing greenhouse gases: maintaining global average temperature increase well below $2{ }^{\circ} \mathrm{C}$ above the pre-industrial levels (UNFCCC, 2015). The definitive position of climatologists of the Intergovernmental Panel on Climate Change had a decisive impact on the setting of the aforementioned objective. They agree that in order to limit temperature increase to $1.5^{\circ} \mathrm{C}$, net-zero $\mathrm{CO}_{2}$ emissions at global level needs to be achieved by the middle of the $21^{\text {st }}$ century, and neutrality for all other greenhouse gases (GHGs) - after 2050. At the same time, if we want to avoid a global natural disaster, any remaining GHG emissions in the energy, industry, transport and housing sectors need to be compensated for by absorption in other sectors, with a specific role for the land use sector, agriculture and forestry (EC, 2018a).Therefore, international opinion leaders strongly supported climate sustainability, which belongs to the so-called strong sustainabilities, on which sustainable economics was built - one of two key trends in the concept of sustainable development. The strong sustainability category means the need to preserve natural assets in the so-called critical natural capital (Jeżowski, 2017). The adoption of the principle of climate sustainability de facto leads to decarbonisation of the world's economy in the long-term perspective.

The European Union has been perceived as the greatest advocate of the principle of climatic sustainability and at the same time the leader of climate change alleviation policy since (in 2005) its flagship became an emission trading system covering over 11,500 installations responsible for $40 \%$ of the total GHG emissions. This is confirmed by EU documents, in particular those referring to the climate and energy policies, such as the $3 \times 20^{1}$ package and the currently binding Europe 2020 strategy (EC, 2010), the 2030 Climate and Energy Framework (EC, 2014) or the 2050 Energy Roadmap (EC, 2018b). In these strategies, the catchphrase of supporting the economy in its effective use of natural resources and in environ-

1 The $3 \times 20$ package is a collection of regulations adopted in 2008 and aimed at counteracting climate change. The package includes e.g. quantitative targets of reducing GHG emissions by at least $20 \%$ as compared to the baseline year 1990, increasing the share of renewable energy sources in final energy consumption to $20 \%$ in 2020 and ment protection implies penalisation of fossil fuels, mainly coal.

It is widely accepted that the transformation of economy towards neutral GHG emission requires dynamic development of technological innovations, interpreted as progression along a sequence of stages from scientific research to applied research, and then to commercialization and diffusion. The EU is at the forefront of new high-value patents for low-carbon technologies, but needs to turn its scientific lead into commercial success. Currently, it is the pilot and demonstration installations that are key elements in meeting the above-mentioned climate challenges (Bossink, 2015, Frishammar et al., 2014). In 2009, the EU set up a new instrument to support the supply of commercial low-carbon technologies, nicknamed NER300 (the New Entrans Reserve 300), with a view to financing demonstration projects in the area of carbon capture and storage (CCS) and financing innovative technology projects in the renewable energy sector during the third phase of the EU ETS (2013-2020).

The NER300 programme is the subject of this article. The article attempts to answer the following questions:

- Was the NER300 programme successful or not?

- What determined its outcomes?

- Should the program become a structural element of the EU ETS?

The article presents the results of NER300 and their interpretation in the context of its objectives and overall intent. The outcomes discussed refer to the projects submitted in both the first and the second round of calls for funding proposals. Research on the determiners of the program results made use of the existing literature on the programme and the special report on its implementation by the European Court of Auditors (ECA, 2018). The literature includes the evaluation of NER300 results for CCS projects following the closure of the first round of calls to the program (Lupion, Herzog, 2013; Scott, 2013), the studies evaluating the program implementation process based on the criteria set after its implementation

increasing energy efficiency by $20 \%$ by 2020 . The package was then expanded to the year 2030: $32 \%$ of energy from renewables, increase of energy efficiency to $32,5 \%$, further reduction of the greenhouse gases to $40 \%$ (in relation to the level from the year 1990). 
(Boasson, Wettestad, 2014; Chiavari, 2010; Fallmann, Heller et al., 2015) and the research focused on how the policies dealing with the demand and supply of low-emission technologies interact with the political feasibility of the programme ( $\AA$ hman et al., 2018).

\section{Theoretical context of the NER 300 programme}

The NER300 programme was formally established on the basis of Article 10a(8) of the EU ETS Directive as amended in 2009 (EU, 2009), according to which up to 300 million allowances in the new entrants' reserve shall be available until 31 December 2015 to help stimulate the construction and operation of up to 12 commercial demonstration projects that aim at the environmentally safe capture and geological storage (CCS) of $\mathrm{CO}_{2}$ as well as demonstration projects of innovative renewable energy technologies, in the territory of the Union.

By establishing a new instrument supporting the supply of low-emission technologies, the European politicians seem to draw on the latest theoretical achievements of the theory of innovation. The most important claim of this theory is that a technology valley of death exists, from which promising technologies fail to emerge due to weak incentives for investment (Nemet et al., 2018). This thesis is formulated generally in relation to innovative technologies in the demonstration phase. This is a sensitive phase, because it occurs in the very middle of the innovation process. Projects in the demonstration phase are already far beyond basic and applied research, but they are not commercial products yet and therefore it is not absolutely clear whether they will succeed or fail commercially (Hendry, Harborne, 2011). This explains why private companies do not fully want to invest in demonstration projects, which are of inherently unproven technical reliability, and with uncertain market response to products made using new technologies.

Researchers agree that in order to avoid the valley of death, it is necessary to secure public financial support for demonstration projects, including in particular those considered to be radical technological innovations related to the energy sector. The investment required to finance a single project of this type can be of tens or even hundreds of millions of euros. It may even happen that several demonstration installations will have to be built to sufficiently prove that this will reduce the risks associated with a breakthrough technology and that the project is suitable for commercial deployment. It cannot be excluded that the required investment expenditures on a particular installation will compete with the value of investing companies, which would make it a potential threat to them or cause them to abandon the project (Sahal, 1985).

\section{NER300 programme results}

The very idea of establishing the NER300 programme can be considered a highly innovative idea: it boils down to inventing new EU money that is not included in the EU budget (Ahman, et al., 2018). The EU assumed that in the years 2014-2020 at least 20\% of its budget will be climate-related expenditure (EU, 2018b), which was an assumption sufficient to give these expenditures a priority. At the same time, the EC decided to propose - and to effectively carry out during the third ETS settlement period - a centralization of the system by abolishing the plans for national GHG emission rights and using the auction system as a basic allocation vehicle instead of charge-free allocation (EC, 2009; Skjærseth. Wettestad, 2010). It also proposed that Member States use a part of revenues from auctioning allowances for emission reduction purposes, including the development of low-carbon technologies. This proposal is a non-binding recommendation only, but the launch of the NER300 programme can have an indirect impact on the actual implementation of this recommendation. The launch of the programme was also intended to cause a direct, additional increase in the level of climate-related expenditure. It was supported with EUR 2.1 billion from the sale of 300 mil-

Table 1. Key features of the implementing decision, source: own work, based on (EC, 2010).

\begin{tabular}{|l|l|}
\hline Management & $\begin{array}{l}\text { The EIB manages the monetization of } \\
\text { emission allowances, controls and } \\
\text { approves the technical and financial } \\
\text { aspects of projects; } \\
\text { Two open rounds of calls for pro- } \\
\text { posals for funding addressed to Mem- } \\
\text { ber States. }\end{array}$ \\
\hline Procedure & $\begin{array}{l}\text { 1. States submit applications upon } \\
\text { determining that the eligibility } \\
\text { criteria for the EIB are met; } \\
\text { 2. EIB evaluates and ranks projects } \\
\text { submitted according to their unit } \\
\text { cost; }\end{array}$ \\
$\begin{array}{l}\text { 3. The EC decides to grant financing; } \\
\text { 4. The states concerned confirm the } \\
\text { decision. }\end{array}$ \\
\hline $\begin{array}{l}\text { Financial } \\
\text { quirements } \\
\text { re- No single project's value may ex- } \\
\text { gramme; of total budget of the pro- } \\
\text { 2. Co-financing should be only com- } \\
\text { plementary to the basic contribution } \\
\text { from the project contractor; } \\
\text { 3. The subsidy is only paid when the } \\
\text { project has been completed. }\end{array}$ \\
$\begin{array}{l}\text { 1. Geographic diversification: at least } \\
\text { 1 and no more than 3 projects should } \\
\text { be co-financed by each state; } \\
\text { 2. Technical diversification: within } \\
\text { the first round of calls, 8 CCS pro- } \\
\text { jects and 1 project in each RES cate- } \\
\text { gory should obtain financing; } \\
\text { 3. Eligible technologies cover 38 cat- } \\
\text { egories (34 for RES and 4 for CCS). }\end{array}$ \\
\hline Technological \\
criteria
\end{tabular}


Table 2. Overview of the NER 300 programme as of March 2018, source: (ECA, 2018)

\begin{tabular}{|c|c|c|c|c|}
\hline State & Category & $\begin{array}{l}\text { Max. amount of fund- } \\
\text { ing granted } \\
(€ \mathrm{mln})\end{array}$ & $\begin{array}{l}\text { Final investment deci- } \\
\text { sion date } *\end{array}$ & Status \\
\hline Italy & Bioenergy & 28 & 2011 & In operation \\
\hline Germany & Bioenergy & 22 & $19 / 08 / 2011$ & In operation \\
\hline Sweden & Wind energy & 15 & $06 / 02 / 2014$ & In operation \\
\hline Germany & Wind energy & 113 & $29 / 06 / 2015$ & In operation \\
\hline Germany & Wind energy & 70 & $18 / 12 / 2014$ & \\
\hline Austria & Wind energy & 11 & $04 / 12 / 2014$ & In operation \\
\hline Finland & Bioenergy & 89 & $31 / 12 / 2016$ & In operation \\
\hline UK & Ocean energy & 17 & $14 / 12 / 2016$ & \\
\hline Cyprus & Concentrated solar energy & 47 & $28 / 12 / 2016$ & \\
\hline Greece & Concentrated solar energy & 45 & $12 / 12 / 2016$ & \\
\hline Greece & Concentrated solar energy & 42 & $14 / 12 / 2016$ & \\
\hline Hungary & Geothermal energy & 39 & $14 / 12 / 2016$ & \\
\hline Portugal & Wind energy & 30 & $17 / 12 / 2016$ & \\
\hline France & Wind energy & 34 & $11 / 07 / 2016$ & \\
\hline Poland & Bioenergy & 31 & & Withdrawn \\
\hline Belgium & Smart grids & 8 & & Withdrawn \\
\hline France & Bioenergy & 170 & & Withdrawn \\
\hline Netherlands & Bioenergy & 199 & & Withdrawn \\
\hline Sweden & Bioenergy & 59 & & Withdrawn \\
\hline UK & Ocean energy & 21 & & Withdrawn \\
\hline
\end{tabular}

* the final investment decision is made by the company's board after preparing the preliminary design and engineering brief, obtaining all the necessary permits and confirming the sources of financing for the entire investment.

lion emission allowances and another EUR 70 million obtained through the European Investment Bank's (EIB) management of the allocated, but not yet paid in, financial resources of the program. This makes the NER300 programme one of the world's largest funding programs for innovative demonstration projects in the area of low-carbon energy (ECA, 2018).

The programme was launched in 2010 under an EC implementing decision (EC, 2010). The key features of the implementing decision are presented in Table 1 .

The European Commission awarded 1.8 billion from the NER300 programme funds to 38 projects during the first (December 2012) and the second (July 2018) round of calls for proposals for funding (ECA, 2018). Table 2 presents the programme implementation stage as of March 2018 with regard to the first round of calls for proposals for funding.

As results from the above data, out of the twenty projects which were granted funding from the NER300 program, fourteen projects related to renewable energy sources obtained the final financing decision.

Among the implemented technological projects there were none related to photovoltaics or smart grids. The projects were related to the following subcategories of renewable energy sources: bioenergy (3), wind energy (6), ocean energy (1), geothermal energy (1), and concentrated solar energy (2). The beneficiaries of the program were $11 \mathrm{EU}$ Member Countries, with Germany (3) and Greece (2) implementing the maximum admissible number of projects. EUR 488 million will not be spent due to the withdrawal of six projects.
Table 3 is an overview of the NER300 status as of March 2018 (second open round of calls for proposals for funding).

In the second round of calls, funding from the NER 300 program covered one CCS project and 18 projects related to renewable energy sources, but only 16 final investment decisions in the field of renewable energy sources were obtained. The projects implemented are related to the following sub-categories of renewable energy sources: bioenergy (5), photovoltaics (1), concentrated solar energy (2), wind energy (2), geothermal energy (2), smart grids (2), and ocean energy (2). The program beneficiaries included ten Member States, with Cyprus, Estonia, France, Italy and Portugal implementing 2 projects each. EUR 352 million will not be spent due to the withdrawal of one CCS project and two projects related to renewable energy sources.

In total, Member States submitted 111 applications for grants from the NER 300 programme to the EIB under two calls for proposals. The Commission confirmed the eligibility of 94 projects and the EIB reported positive due diligence assessments for 83 (i.e. $88 \%$ ) of those projects. Finally, as of March 2018, the NER 300 programme will finance 30 projects related to renewable energy sources (27\% of applications), for which a final investment decision has been taken (six of them are already in operation). Within the programme, no CCS project will be implemented. The project will not have utilized an amount of approx. EUR 840 million from its budget. In the light of these data, it can be concluded that the NER 300 programme failed in terms of its effectiveness, especially with regard to CCS. 
Table 3. Overview of the NER 300 programme as of March 2018, source: (EC, 2018)

\begin{tabular}{|c|c|c|c|c|}
\hline State & Category & $\begin{array}{l}\text { Max. amount of } \\
\text { funding granted } \\
(€ \mathrm{mln})\end{array}$ & $\begin{array}{l}\text { Final investment deci- } \\
\text { sion date }\end{array}$ & Status \\
\hline Cyprus & Concentrated solar energy & 60 & & \\
\hline Cyprus & Smart grids & 11 & 30.06 .2018 & \\
\hline Denmark & Bioenergy & 39 & 30.06 .2018 & \\
\hline Estonia & Bioenergy & 7 & 30.06 .2018 & \\
\hline Estonia & Bioenergy & 25 & 30.06 .2018 & \\
\hline Spain & Wind energy & 33 & 30.06 .2018 & \\
\hline Spain & Wind energy & 34 & 30.06 .2018 & \\
\hline France & Geothermal energy & 17 & 30.06 .2018 & \\
\hline France & Ocean energy & 72 & 30.06 .2018 & \\
\hline Croatia & Geothermal energy & 15 & 30.06 .2018 & \\
\hline Italy & Concentrated solar energy & 40 & 30.06 .2018 & \\
\hline Italy & Smart grids & 85 & 30.06 .2018 & \\
\hline Latvia & Bioenergy & 4 & 30.06 .2018 & \\
\hline Portugal & Ocean energy & 9 & 30.06 .2018 & \\
\hline Portugal & Photovoltaics & 8 & 30.06 .2018 & \\
\hline Sweden & Bioenergy & 204 & 30.06 .2018 & \\
\hline Spain & Bioenergy & 29 & & Withdrawn \\
\hline Ireland & Ocean energy & 23 & & Withdrawn \\
\hline UK & CCS & 300 & & $\begin{array}{l}\text { Withdrawal in } \\
\text { progress }\end{array}$ \\
\hline
\end{tabular}

\section{Main reasons of the NER300 programme failure}

Factors delaying the intended progress of demonstration projects under the NER300 program are both internal and external. The internal factors should be linked to a study of whether the very concept of the programme did not contribute to its failure. The literature survey, the analysis of EU documents and the results of audits by the European Court of Auditors (ECA) demonstrate that, indeed, significant causes for the NER300 programme failure are inherent to its design. These include:

- basing the programme's revenues on market prices of GHG emission allowances,

- lack of programme flexibility,

- not fully transparent and clear criteria for the selection of demonstration projects,

- lack of effective supervision over the programme,

- lack of programme accountability.

The main element of the NER300 program is that its funds are secured by GHG emission rights auctions, and consequently their amount depends on their issue price. The revenues from the sale of 300 million allowances were expected to amount to EUR 6-9 billion, the amount considered to constitute the absolute minimum to achieve the ambitious goals of the programme. However, at the turn of 2008 and 2009 allowance prices fell and the EIB managed to collect only EUR 2.1 billion. This resulted in a largescale reduction of project financing. The EU could have designed the total financing of the program so as to make it less dependent on allowance prices by coordinating it with other programmes supporting the development of low-emission technologies, including, for instance, with the European Energy Program for Recovery (EEPR) and InnovFin Energy Demo Projects. Unfortunately, these programmes were developed by various EC teams and at different times.

The EC awarded grants from the NER300 program to projects based on the list of admissible technologies and their threshold values as established in 2009. Determination of more detailed technological criteria in advance carries the risk that rapid technological and market changes will make the projects selected on their basis far from a breakthrough. The legal framework of the program did not provide for any reviews of the list or of the projects submitted, any extended deadlines for submitting the applications or creation of any waiting lists. This could have made promising technologies and projects excluded despite the accumulation of funds earmarked for projects that were initially qualified for financing but later on withdrawn by individual states.

The Commission and the EIB have developed a manual of procedures on the basis of which the EIB should conduct evaluation of the due diligence (i.e. technical and financial feasibility) of projects. However, the evaluation scheme did not provide for project scoring or their ranking in terms of the extent to which the applications met the individual evaluation criteria (no evaluation grid of specific criteria had been prepared) which would have rationalized the selection of projects. The criterion of the so-called technology readiness level (TRL) was not assigned a correct weight (Report, 2017). The EIB was also not required to evaluate the economic feasibility of projects, i.e. the ability to clearly demonstrate a source of income during the installation's operation phase that would allow debt servicing and ROI generation. 
This increases the risks of project contractor, but also those related to the public donor's inefficiency.

The EC bears overall responsibility for the program by implementing coordination activities covering the Member States and the EIB. However, it has not been equipped with such important instruments as mandatory reports on the annual progress in implementing the Member States' projects or mandatory, binding declarations on national contributions to project financing. The lack of such declarations was the main reason of withdrawing projects from the program during its operation (this refers, inter alia, to the Polish CCS project).

The program's resources do not count towards the EU's general budget. The legal instruments establishing the program do not contain any reference to financial control or any internal or external audits. The EC is not legally obligated to prepare annual reports on the operational and financial outcomes of the program in order to ensure its full financial accountability, which significantly violates the principle of transparency of public expenditure. Also, no procedure of EIB discharge for managing the NER300 program funds is used.

With regard to some projects, two or more of the aforementioned reasons occurred. This was the case, for instance, with CCS demonstration projects, the failure of which corresponds to the first three of the aforementioned causes. The CCS technology was seen as a panacea for the need to reconcile GHG emission reductions with the actual, widespread use of coal in energy generation and energy-intensive industries. While adopting the " $3 \times 20 \% "$ energy and climate package, the EC hoped very much that it would ensure a profound reduction of $\mathrm{CO}_{2}$ emissions from industrial installations (EC, 2008). As the technology still required fine-tuning to be brought to the level necessary for its commercialization, the EC initially decided to have 8-12 large scale demonstration projects (with a minimum capacity of $250 \mathrm{MW}$ ) launched by 2016 in power plants and energy-intensive industries. The costs of CCS implementation were assessed by several institutions, including the EU Joint Research Centre, the Carbon Sequestration Leadership Forum, and the European Zero-Emission Platform. It was found that with the first generation of CCS power plants, the construction costs would be particularly high, amounting to EUR 40-90 per tonne of emissions avoided. Therefore, to encourage entrepreneurs to create the installations, support was required at the levels of full coverage of capital investment and partial coverage of operational costs. The cost of a single standard demonstration project varies between 500 and 1000 million euros. The NER300 support would be possible at EUR 337.5 million, with a cap of $50 \%$ of the total expenditure (Radgen et al. 2013).

Among external factors delaying the intended progress of demonstration projects implemented under the NER300 program, there were:
- unfavorable investment climate for lowemission energy,

- controversy and lack of public acceptance of CCS technologies.

During the NER300 programme's calls for applications for funding of demonstration projects, the emergence of unfavourable investment climate for lowemission energy was caused by two major factors. The first one was related to a significant drop in coal prices as compared to the drop in oil and gas prices at the global wholesale market in 2009, just before the launch of NER300 (Lupion, Herzog, 2013). The relatively larger drop in coal prices made investments in new low-carbon energy technologies less attractive as compared to the technologies based on fossil fuels. The other factor was political and regulatory uncertainty at the EU and national levels, which requires a more detailed explanation. It is a fact that the NER300 program is an instrument supporting the supply of commercial low-carbon technologies. However, the interest of potential investors in demonstration projects making use of these technologies depends not only on the policies supporting technology supply (technology-push policies), but also on stimulation of the demand for products manufactured using lowemission technologies (demand-pull policies). After all, private investment in demonstration projects should ensure return of capital. Starting from the 1990s, there has been a political trend of supporting electricity generated from renewable sources and of supporting biofuels in transport. This was initially motivated by the security of energy supplies, and then by the climate policies. At the EU level, those policies included quantitative targets of implementation (reduction of GHG emissions by $20 \%$, share of renewable sources in transport to be increased by up to $10 \%$ ). However, the competence regarding the mechanisms/instruments to achieve these objectives has remained with the Member States. Electricity generated from renewable sources has been generously supported in most EU Member States (guaranteed tariffs, green certificates for renewable energy). However, during the post-crisis period, the financial support policies began to change in many countries. Biofuels, in turn, have never enjoyed such a large and stable public support due to concerns about sustainable development and global food production. Since 2009, progress in stimulating the demand for biofuels in the EU has been very slow, and their share in the fuel market actually has gone down in many Member States (Skjærseth, Wettestad, 2010). All this shows a clear relationship between the failure of NER300 and its structuring as well as market policies of the EU and the Member States (Åhman et al., 2018).

Specialists, and especially ordinary EU citizens, present different, often contradictory and emotional opinions about CCS technology (Broecks et al., 2016). Also many projects, especially those involving $\mathrm{CO}_{2}$ storage on land, encountered a barrier of social resistance. Some Member States (e.g. Germany) have 
introduced either a ban or restrictions on the storage of carbon dioxide in their territory. This created an unfavourable social climate for the CCS demonstration projects.

\section{Will the failure of the NER300 program get trans- formed into the success of the ETS Innovation Fund?}

Despite the failure of the NER300 program, the core idea underlying its launch has been approved by all EU Member States thanks to its geographical criterion that guarantees the political efficiency of the program. The idea is to strengthen market signals so that the groundbreaking demonstration projects with a potential to decarbonise the European economy could leave the technological valley of death by 2050 . A program which would co-finance low-carbon technologies should be a stable component of the EU ETS, which has also happened.

In their progress report on the implementation of 2015 Climate Action Program, the EC proposed another program - the Innovation Fund, which is a modification of the NER300 (EC, 2015). This proposal was accepted and the Fund's cornerstones were established in the amended ETS Directive of March 2018 (EU, $2018 b$ ). This gives rise to the question whether the revealed reasons for the failure of the NER300 program have been/will be removed during the work on structuring the Innovation Fund at the level of the implementing decision or, in other words, whether the knowledge and experience gained will contribute to the success of modified program. For this to happen, it is necessary to discuss the reasons for the failure of the NER300 among the researchers and experts.

The directive decided on two important components of the Innovation Fund structure. First, the Fund will be financed with revenues from the auction of 400 million GHG emission allowances drawn from the new installations reserve, revenues from the sale of 50 million allowances drawn from the Financial Stability Reserve, and the funds unutilised under the NER300 programme from 2013 to 2020 . The increased budget will certainly create new financing opportunities for large, groundbreaking demonstration projects. However, the actual volume of the Fund will continue to depend on the market price of GHG emission allowances. Nevertheless, it is reasonable to expect that the creation of the Financial Stability Reserve within the EU ETS will provide greater stability for that price. At the same time, the reduction rate for the total cap on allowances will be accelerated from $1.7 \%$ to $2.2 \%$ between 2021 and 2030, making it possible to maintain the price at a relatively high level.

The other modification in the Innovation Fund project consists in increasing the possibility of paying out the subsidies granted at the advanced stages of demonstration projects implementation, called milestones, which for investment promoters will reduce the need for working capital and significantly reduce overall capital expenditure.

Thus, the question asked in this part of discussion is rhetorical only, due to the lack of the implementing decision on the modernized EU program for co-financing the supply of low-emission technologies.

\section{Conclusion}

The NER300 program was originally proposed to demonstrate the advantages of CCS and breakthrough low-carbon technologies on a large scale. The programme's objective hasn't been met. Instead, the program financed a number of smaller and less technologically advanced demonstration projects related to renewable energy. The EU proposed a new financial instrument to stimulate the supply of breakthrough technologies - the ETS Innovation Fund, as well as a more comprehensive package of 2020-2030 climate policies, aimed at changing the investment climate for various low-carbon technologies in Europe - and hence the Innovation Fund is more likely to attract private capital for new or deferred large-scale demonstration projects. The lack of the Fund's implementing decision creates an excellent opportunity to discuss the desirable structure of the Fund.

\section{References}

1. ÅHMAN M., SKJEAERSETH J.B., EIKELAND P.O., 2018, Demonstrating climate mitigation technologies: An early assessment of the NER300 programme, in: Energy Policy, 117, p. 100-107.

2. BOASSON E.L., WETTESTAD J., 2014, Policy invention and entrepreneurship: Bankrolling the burying of carbon in the EU, in: Global Environmental Change, 29, p. 404-412.

3. BOSSINK B.G., 2015, Demonstration projects for diffusion of clean technological innovation: a review, in: Clean Technologies and Environmental Policy, 17, p. 1409-1427.

4. BROECKS K.P.F., VAN EGMOND S., VAN RIJNSOEVER F.J., VERLINDE-VAN DEN BERG M., HEKKERT M.P., 2016, Persuasiveness, importance and novelty of arguments about Carbon Capture and Storage, in: Environmental Science \& Policy, 59, p. 58-66.

5. CHIAVARI J., 2010, The legal framework for carbon and capture and storage in the EU (Directive 2009/31/EC), in: New Climate Policies of the European Union, eds Oberthur, S., Kelly, C.R., Pallemaerts, M., VUB Press, Brussels.

6. EC, 2010, Commission decision 2010/670/EU of 3 November 2010 laying down criteria and measures for the financing of commercial demonstration projects that aim at the environmentally safe capture and geological storage of $\mathrm{CO}_{2}$ as well as demonstration projects of innovative renewable energy technologies under the scheme for greenhouse gas emission allowance trading within the Community established by Directive 2003/87/EC of the European Parliament and of the Council, in: OJ L, 290(39), 6.11.2010. 
7. EC, 2010, Communication from the Commission Europe, A strategy for smart, sustainable and inclusive growth. COM (2010) 2020 final, Brussels, 3.3.2010, COM (2014) 15 final, Brussels, 22.1.2014.

8. EC, 2014, A policy framework for climate and energy in the period from 2020 to 2030, COM (2014) 15 final, Brussels, 22.1.2014.

9. EC, 2015, Report from the Commission to the European Parliament and the Council. Climate action progress report, including the report on the functioning of the European carbon market and the report on the revieu of Directive 2009/31/EC on the geological storage of carbon dioxide, $\operatorname{COM}(2015) 576$ final, Brussels, 18.11.2015.

10. EC, 2018 a, Communication from the Commission to the European Parliament, the European Council, the Council, the European Economic and European Investment Bank. A Clean Planet for all European strategic long-term vision for a prosperous, modern, competitive and climate neutral economy, COM (2018) 773 final, Brussels, 28.11.2018.

11. EC, 2018b, Report from the Commission to the European Parliament and the Council UE and the Paris Climate Agreement: Taking stock of progress at $\mathrm{Ka}$ towice COP, COM (2018) 716 final, Brussels, 26.2018.

12. ECA, 2018, Demonstrating carbon capture and storage and innovative renewables at commercial scale in the EU: intended progress not achieved in the past decade, in: Special Report No 24, ECA.

13. EC, 2009, Directive 2009/29/EC of the European Parliament and of the Council of 23 April 2009 amending Directive 2003/87/EC so as to improve and extend the greenhouse gas emission allowance trading scheme of the community, in: OJ L, 140(63), 5.6.2009.

14. EU, 2018b, Directive (EU) $2018 / 410$ of the European Parliament and of the Council of 14 March 2018 amending Directive 2003/87/EC to enhance cost-effective emission reductions and low-carbon investments, and decision (EU) 2015/1814, in: OJ L, 76(3), 19.3.2018

15. FALLMANN H., HELLER C., SEUSS J., VOOGT M., RIEDEL A., 2015, The NER 300 Funding, in: Evalluation of the EU ETS Directive carried out within the project'Support for the Review of the EU
Emissions Trading System'. EU Commission \& Environment Agency, Vienna.

16. FRISHAMMAR J., SODERHOLM P., BACKSTROM K., HELLSMARK H., YLINENPAA H., 2014, The role of pilot and demonstration plants in technological development: Synthesis and directions for future research, in: Technology Analysis and Strategic Management, 27, p. 1-18.

17. HENDRY CH., HARBONE P., 2011, Changing the view of wind power development: more than bricolage, in: Research Policy, 40(5), p. 778-789.

18. JEŻOWSKI P., 2017, O niektórych problemach gospodarki niskoemisyjnej, in: Studia z Polityki Publicznej, 1, p. 45-64.

19. LUPION M., HERZOG H.J., 2013, NER 300: lessons learnt in attempting to secure CCS projects in Europe, in: Greenhouse Gas Control Technologies, 9, p. 1925.

20. NEMET G.F., ZIPPERER V., KRAUS M., 2018, The valley of death, the technology pork barrel, and public support for large demonstration projects, in: Energy Policy, 119, p.154-167.

21. RADAGEN P., IRONS R., SCHOENMAKERS H., 2013. Too early or too late for CCS - what needs to be done to overcome the valley of death for Carbon Capture and Storage in Europe, in: Energy Procedia, 37, p. 6189-6201.

22. SAHAL D., 1985, Technological guideposts and innovation avenues, in: Research Policy, 14(2), p. 6182.

23. SCOTT V., 2013, What can we expect from Europe's Carbon capture and storage demonstrations? View Point, in: Energy Policy, 54, p. 66-71.

24. SKJAERSETH J.B., WETTESTAD J., 2010, The EU emissions trading system revisited, Directive 2009/29/EC, in: The New Climate Policies of the European Union, eds Oberthur, S., Kelly, C.R., Pallemaerts, M., VUB Press, Brussels.

25. SUMMARY REPORT, 2017, Finance for innovation: towards the ETS Innovation Fund, https://ec.europa.eu/clima/sites/clima/files/events/docs/0115/201 70612_report_en.pdf (30.12.2018).

26. UNFCCC/CP/2015/L.9, 2015, Framework Convention on Climate Change, Paris, https://unfccc.int/resource/docs/2015/cop21/eng/109r01.pdf $(5.02 .2019)$ 